\title{
Sikap Masyarakat Tani terhadap Pengembangan Kampung Kelor di Desa Kedungbulus Kecamatan Gembong Kabupaten Pati
}

\author{
Farmers Attitude Towards The Development of Kampung Kelor in Kedungbulus Village Gembong \\ District Pati Regency
}

\author{
Agnas Wardhani, Suwarto, Sugihardjo \\ Program Studi Penyuluhan dan Komunikasi Pertanian Fakultas Pertanian \\ Universitas Sebelas Maret \\ J1. Ir. Sutami No.36 A Kentingan Surakarta 57126 Telp/Fax (0271) 637457 \\ Email: agnasw@gmail.com
}

\begin{abstract}
The aims of this research are to analyze farmer's attitudes towards the development of Kampung Kelor; analyzing the relationship between age, formal education, land tenure, non formal education, farming experience, and the influence of others who are considered important towards the development of Kampung Kelor; and differentiating the attitude of farming communities that have and have not tried kelor. The research employed a quantitative method by a survey technique. The research location was Kedungbulus Village with the consideration of Kedungbulus Village, is the only producer of Moringa processed products in Pati Regency which has a production permit for Household Industry (PIRT) and related research and assists the process of making Moringa. The samples were taken by proportional random sampling technique. The data analysis that used is Rank Spearman and U Mann Whitney with the SPSS 20.0 program application for Windows. The results of the study showed that: Farmer's attitudes towards the development of Kampung Kelor (increasing income, educating the community, advancing villages, and increasing food and nutrition security) are good included in the agreed category; the forming factors of community attitudes are significantly related to the farmers attitudes are age (X1), formal education (X2), non-formal education (X4), farming experience (X5), and the influence of others who are considered important (X6), meanwhile the land tenure (X3) is not significantly related; Farmers who have cultivated moringa have a better attitude than farmers that have not cultivated moringa.
\end{abstract}

Keyword: Moringa, Food Security, Attitude, Farmers.

Abstrak: Penelitian ini bertujuan untuk menganalisis sikap masyarakat tani terhadap pengembangan Kampung Kelor; menganalisis hubungan umur, pendidikan formal, luas penguasaan lahan, pendidikan non formal, pengalaman usahatani, dan pengaruh oranglain yang dianggap penting terhadap sikap masyarakat tani pada pengembangan Kampung Kelor, dan menganalisis perbedaan sikap antara masyarakat tani yang sudah mengusahakan kelor dengan yang belum mengusahakan kelor. Lokasi penelitian di Desa Kedungbulus Kecamatan Gembong Kabupaten Pati dengan pertimbangan Desa Kedungbulus merupakan satu-satunya penghasil produk olahan kelor di Kabupaten Pati yang sudah memiliki izin Produksi Industri Rumah Tangga (PIRT) dan terdapat gerakan penanaman serta pengolahan kelor. Teknik pengambilan sampel dengan Proportional random sampling. Analisis data menggunakan korelasi Rank Spearman dan Uji Mann-Whitnney. Hasil penelitian menunjukkan bahwa: Sikap masyarakat tani terhadap tujuan pengembangan Kampung Kelor dalam meningkatkan pendapatan, edukasi masyarakat, memajukan desa, dan meningkatkan ketahanan pangan serta gizi adalah baik; faktor-faktor pembentuk sikap masyarakat tani yang berhubungan signifikan terhadap sikap masyarakat tani yaitu umur $\left(\mathrm{X}_{1}\right)$, pendidikan formal $\left(\mathrm{X}_{2}\right)$, pendidikan non formal $\left(\mathrm{X}_{4}\right)$, pengalaman usahatani $\left(\mathrm{X}_{5}\right)$, dan pengaruh oranglain yang dianggap penting $\left(\mathrm{X}_{6}\right)$, sedangkan luas penguasaan lahan $\left(\mathrm{X}_{3}\right)$ tidak berhubungan secara signifikan; Masyarakat tani yang sudah mengusahakan kelor memiliki sikap yang lebih baik daripada masyarakat tani yang belum mengusahakan kelor.

Kata Kunci: Kelor, Ketahanan Pangan, Masyarakat Tani, Sikap. 


\section{PENDAHULUAN}

Sektor pertanian erat kaitannya dengan pemenuhan kebutuhan pangan masyarakat. Undang-Undang Nomor 18 Tahun 2012 tentang Pangan menerangkan konsep ketahanan pangan sebagai suatu keadaan pangan setiap individu yang stabil akan ketersediaan, aksesibilitas (keterjangkauan), dan stabilitas pengadaannya. Peningkatan ketahanan pangan merupakan prioritas utama pembangunan nasional pertanian untuk mengentaskan kemiskinan dan meningkatkan kesejahteraan rakyat.

Indonesia merupakan negara yang luas dengan angka kemiskinan yang besar. Badan Pusat Statistik (2017) mencatat jumlah penduduk miskin mencapai 26.58 juta jiwa yang terdiri dari penduduk miskin perkotaan sebesar 10.27 juta jiwa dan pedesaan sebesar 16.31 juta jiwa. Data BPS (2017) menyebutkan karakteristik rumah tangga miskin di Indonesia menurut sumber penghasilan utama di daerah tempat tinggal menunjukkan bahwa $49.89 \%$ bekerja di bidang pertanian. Sehubungan dengan hal tersebut, diketahui bahwa sebagian besar masyarakat yang bekerja di sektor pertanian dan berdomisili di pedesaan masih rentan terhadap kemiskinan.

Salah satu upaya mengentaskan kemiskinan di pedesaan yaitu melalui pembangunan pedesaan dengan cara meningkatkan output dan pendapatan masyarakat desa. Undang-undang Nomor 6 Tahun 2014 tentang Desa, menjadi peluang besar bagi setiap desa di Indonesia untuk dapat mengembangkan potensi yang dimiliki secara mandiri. Pemanfaatan potensi kelor sebagai alternatif usaha dan penyediaan bahan pangan bergizi disiasati oleh Komunitas Pangan Sehat (KPS) dengan membuat rintisan pengembangan Kampung Kelor di Desa Kedungbulus Kecamatan Gembong Kabupaten Pati yang diresmikan pada 4 Juli 2016 oleh Bupati Pati melalui gerakan penanaman dan pengolahan kelor. Irfa'i (2011) menyebutkan bahwa lembaga internasional seperti Food and Agricultural Organization (FAO) dan World Health Organization (WHO) mempromosikan tanaman kelor sebagai super food karena kandungan nutrisinya tinggi serta menjadi basis utama dalam memerangi kondisi kurang gizi, lapar gizi, dan berbagai problema kesehatan. Rusmani (2018) menyebutkan tujuan Pengembangan Kampung Kelor yaitu meningkatkan pendapatan melalui tani pekarangan dan menambah jenis tanaman ladang, edukasi masyarakat tentang pentingnya gizi dan budidaya kelor, menjadikan desa sebagai sentra kelor yang dapat menjadi peluang wisata, dan meningkatkan ketahanan pangan serta gizi masyarakat.

Keberhasilan menyukseskan Kampung Kelor yang melibatkan pemerintah, komunitas lokal, dan masyarakat tani sangat ditentukan oleh sikap masyarakat itu sendiri. Oskamp dan Wesley (2014) menyatakan semakin baik sikap yang ditimbulkan maka semakin baik pula proses yang dijalankan. Berdasarkan survei awal yang dilakukan di Kampung Kelor, diduga sikap masyarakat tani terhadap kegiatan pengembangan belum optimal. Pengembangan Kampung Kelor masih bersifat baru dan belum diketahui secara jelas apakah masyarakat tani setuju atau tidak terhadap kegiatan tersebut sehingga penelitian ini perlu dilakukan sebagai upaya menyukseskan pengembangan potensi desa yang berdayaguna dan hasil.

\section{METODE PENELITIAN}

Penelitian ini menggunakan metode penelitian kuantitatif dengan teknik survey. Lokasi penelitian di Desa Kedungbulus Kecamatan Gembong Kabupaten Pati. Daerah ini merupakan satu-satunya penghasil produk olahan kelor di Kabupaten Pati yang sudah memiliki izin Produksi Industri Rumah Tangga (PIRT) dan terdapat gerakan penanaman serta pengolahan kelor. Populasi dalam penelitian adalah masyarakat tani yang bertempat tinggal di kawasan Kampung Kelor berjumlah 97 orang (kelompok tani Rukun Tani 77 orang dan kelompok wanita tani Karya Mulya 20 orang) di Dusun Kedungbulus Kidul Desa Kedungbulus Kecamatan Gembong Kabupaten Pati. Penarikan sampel pada penelitian ini dengan menggunakan teknik Proportional random sampling. Menurut Singarimbun dan Effendi (1989) data yang dianalisis harus menggunakan jumlah sampel yang jumlahnya lebih besar atau sama dengan 30 , sehingga penelitian ini mengambil sampel sejumlah 60 responden. Sumber data yang digunakan adalah sumber primer dan sekunder. 
Jenis data yang digunakan adalah data kuantitatif dan data kualitatif. Teknik pengumpulan data dilakukan dengan cara observasi, wawancara, kuesioner dan penelusuran literatur.

Metode analisis data yang digunakan dalam penelitian ini adalah koefisien korelasi yang analisisnya dititikberatkan dalam hubungan. Selain itu, dilakukan beberapa uji lainnya yakni, uji validitas dengan pengambilan sampel sebanyak 20 responden dengan nilai $r$ tabel sebesar 0,444, kemudian dilakukan uji reliabilitas yang diukur dengan ketentuan nilai cronbach alpha $>0,60$. Hasil dari uji reliabilitas pada penelitian ini sebesar 0,792 lebih dari 0,60 yang berarti data penelitian dinyatakan reliabel. Analisis Rank Spearman bertujuan untuk mengetahui hubungan antara variabel independen dengan variabel dependen, sedangkan uji t untuk menguji tingkat signifikansi hubungan. Uji beda Mann-Whitnney dilakukan untuk mengetahui perbedaan sikap antara masyarakat yang sudah mengusahakan kelor dengan yang belum mengusahakan kelor.

\section{HASIL DAN PEMBAHASAN}

Desa Kedungbulus merupakan desa yang terletak di Kecamatan Gembong Kabupaten Pati. Desa Kedungbulus memiliki luas wilayah 512 ha yang terdiri dari 62 ha $(12,11 \%)$ lahan sawah, 356 ha $(69,5 \%)$ lahan pertanian bukan sawah, dan 94 ha bukan lahan pertanian. Terbatasnya lahan sawah menjadikan masyarakat tani harus memanfatkan lahan bukan sawah untuk budidaya pertanian, salah satunya dengan mengusahakan kelor. Pemanfaatan lahan bukan sawah untuk kegiatan pertanian di Desa Kedungbulus diharapkan dapat menjadi alternatif dalam pemenuhan konsumsi rumah tangga dan meningkatkan pendapatan masyarakat tani sehingga keterbatasan lahan sawah bukan menjadi hambatan besar untuk meningkatkan kesejahteraan.
Kelor menjadi salah satu tanaman yang banyak dikembangkan di Desa Kedungbulus dan pada tahun 2018 sudah terdapat lebih dari 15.000 pohon kelor di Desa Kedungbulus. Mayoritas masyarakat tani membudidayakan kelor di lahan dengan luasan 0,2 ha. Produksi daun basah dengan luas 0,2 ha sebesar $200 \mathrm{~kg}$ per bulan. Kelor dipanen dua minggu sekali, jadi dengan luas kebun 0,2 ha memiliki potensi produksi 400 $\mathrm{kg}$ per bulan. $2 \mathrm{~kg}$ daun basah apabila dikeringkan menjadi $1 \mathrm{~kg}$ daun kering. Hasil daun kelor kering dijual Rp. $10.000,00$ per kg. Rata-rata pendapatan masyarakat tani dari budidaya kelor adalah Rp. 2.000.000,00 per bulan. Kelor di Desa Kedungbulus diolah menjadi teh, mie, keripik, pangsit, dan minyak kelor. Prospek tanaman kelor di Desa Kedungbulus semakin baik dengan terlibatnya pada berbagai perlombaan dan pameran pangan tingkat Kabupaten. Budidaya kelor di Desa Kedungbulus didukung oleh sosialisasi, pelatihan, dan penyuluhan dari Dinas Pertanian dan Komunitas Pangan Sehat. Masyarakat tani yang membudidayakan kelor dapat menjual daun kelor segar kepada CV. Mahakarya Mulya di Desa Kedungbulus dan atau mengolahnya sendiri menjadi produk pangan untuk konsumsi rumah tangga dan dipasarkan. Hingga saat ini, produk olahan kelor di Desa Kedungbulus menjadi satusatunya produk olahan kelor Kabupaten Pati yang memiliki PIRT.

\section{Sikap Masyarakat Tani terhadap Pengembangan Kampung Kelor di Desa Kedungbulus Kecamatan Gembong Kabupaten Pati.}

Sikap masyarakat tani terhadap pengembangan Kampung Kelor di Kecamatan Gembong diukur dengan mencatat jawaban responden dalam bentuk pernyataan positif dan negatif mengenai tujuan pengembangan Kampung Kelor yaitu meningkatkan pendapatan, edukasi masyarakat, memajukan desa, dan meningkatkan ketahanan pangan serta gizi masyarakat. Distribusi tingkat sikap masyarakat tani terhadap pengembangan Kampung Kelor dapat dilihat pada Tabel 1. 
Tabel 1. Distribusi sikap masyarakat tani terhadap pengembangan Kampung Kelor di Desa Kedungbulus Tahun 2018.

\begin{tabular}{|c|c|c|c|c|c|}
\hline \multirow{2}{*}{ No. } & \multirow{2}{*}{ Sub variabel } & \multirow{2}{*}{ Kategori } & \multirow{2}{*}{ Skor } & \multicolumn{2}{|c|}{ Distribusi } \\
\hline & & & & $(\mathrm{N})$ & $(\%)$ \\
\hline 1 & Meningkatkan pendapatan & Setuju & $30,9-38,1$ & 45 & 75,00 \\
\hline 2 & Edukasi masyarakat & Setuju & $34,3-42,3$ & 31 & 51,66 \\
\hline 3 & Memajukan desa & Setuju & $30,9-38,1$ & 30 & 50,00 \\
\hline 4 & $\begin{array}{l}\text { Meningkatkan ketahanan } \\
\text { pangan dan gizi masyarakat }\end{array}$ & Setuju & $34,3-42,3$ & 37 & 61,67 \\
\hline
\end{tabular}

Berdasarkan Tabel 1 dapat diketahui bahwa sikap masyarakat tani terhadap tujuan pengembangan Kampung untuk meningkatkan pendapatan termasuk dalam kategori setuju atau baik sebanyak 45 responden $(75,00 \%)$. Pengembangan Kampung Kelor dapat menjadi alternatif usaha pertanian di pedesaan yang bernilai ekonomi. Olahan kelor memiliki nilai jual yang perlu dipertimbangan untuk dapat menambah pendapatan masyarakat tani.

Sikap masyarakat tani terhadap tujuan pengembangan Kampung Kelor untuk edukasi masyarakat diketahui mayoritas memiliki sikap setuju atau baik sebanyak 31 responden $(51,66 \%)$. Melalui pengembangan Kampung Kelor, masyarakat tani memiliki peluang dalam menyerap sebanyak-banyaknya informasi baru terkait budidaya dan pengolahan kelor yang bermanfaat bagi kehidupan.

Sikap masyarakat tani terhadap tujuan pengembangan Kampung untuk memajukan desa termasuk dalam kategori setuju atau baik sebanyak 30 responden $(50,00 \%)$. Pengembangan Kampung Kelor bertujuan untuk mengoptimalkan potensi kelor yang banyak tersedia di Desa Kedungbulus sehingga memberi peluang besar untuk Desa Kedungbulus dikenal secara lebih luas. Lebih lanjut dapat memberi peluang kerjasama atau kemitraan usaha kelor.

Sikap masyarakat tani terhadap tujuan pengembangan Kampung Kelor untuk meningkatkan ketahanan pangan dan gizi masyarakat mayoritas termasuk dalam kategori setuju sebanyak 37 responden $(61,67 \%)$. Daun kelor mengandung jumlah nutrisi yang tinggi (per $100 \mathrm{~g}$ segar berat badan) vitamin A, vitamin C (51,7 mg), kalsium (185mg) dan kalium (337mg) (Radovich, 2010). Kelor memiliki potensi meningkatkan gizi, meningkatkan ketahanan pangan, dan mendorong pembangunan pedesaan (Adedokum et al., 2010).

Hubungan Umur (X1), Pendidikan Formal (X2), Luas Penguasaan Lahan (X3), Pendidikan Non Formal (X4), Pengalaman Usahatani (X5), dan Pengaruh Orang lain yang Dianggap Penting (X6) dengan Sikap Masyarakat Tani pada Pengembangan Kampung Kelor di Desa Kedungbulus.

Berikut ini disajikan tabel faktor-faktor pembentuk sikap masyarakat tani terhadap pengembangan Kampung Kelor berdasarkan analisis distribusi frekuensi responden. 
Tabel 2. Distribusi Faktor-faktor pembentuk sikap masyarakat tani terhadap pengembangan Kampung Kelor di Desa Kedungbulus Kecamatan Gembong Kabupaten Pati.

\begin{tabular}{lllcr}
\hline \multirow{2}{*}{ No } & Variabel & \multirow{2}{*}{ Kategori } & \multicolumn{2}{c}{ Distribusi } \\
\cline { 4 - 5 } & & & $\mathrm{N}$ & $\%$ \\
\hline 1 & Umur & Produktif & 38 & 63,33 \\
2 & Pendidikan Formal & Sedang & 28 & 46,66 \\
3 & Luas Penguasaan Lahan & Sempit & 25 & 41,67 \\
4 & Pendidikan Non Formal (tahun 2018) & Rendah & 15 & 25,00 \\
& & Sangat tinggi & 15 & 25,00 \\
5 & Pengalaman Usahatani & Cukup berpengalaman & 25 & 41,67 \\
6 & Pengaruh orang lain yang dianggap penting & Cukup berpengaruh & 19 & 31,66 \\
& (tahun 2018) & & \\
\hline
\end{tabular}

Berdasarkan Tabel 2 dapat diketahui bahwa mayoritas umur responden masuk dalam kategori produktif 15-64 tahun sebanyak 38 orang $(63,33 \%)$. Petani di Desa Kedungbulus ratarata berumur 48-56 tahun. Umur mempengaruhi seseorang dalam merespon sesuatu yang baru. Petani yang memiliki umur produktif mempunyai kemampuan fisik yang kuat untuk mengembangkan usahataninya (Darwis, 2017).

Tingkat pendidikan formal petani responden mayoritas SMP yakni berkategori sedang 46,66 \% dengan jumlah petani sebanyak 28 orang. Petani dengan pendidikan lebih tinggi cenderung responsif terhadap penerimaan inovasi-inovasi baru, termasuk pengembangan Kampung Kelor. Tingkat pendidikan yang tinggi akan memudahkan responden dalam menerima inovasi baru.

Petani di Desa Kedungbulus mayoritas memiliki lahan garapan dengan luasan 0,21- 0,4 ha dengan jumlah petani 25 orang $(41,67 \%)$. Hal tersebut menunjukkan bahwa luas lahan yang digarap petani responden termasuk dalam kategori sempit. Menurut Manatar et al., (2017) lahan yang luas akan memperbesar harapan petani untuk hidup layak.

Pendidikan non formal yang diukur dalam penelitian adalah frekuensi responden dalam mengikuti pendidikan non formal seperti sosialisasi, pelatihan, dan penyuluhan terkait pengembangan Kampung Kelor dalam satu tahun terakhir. Mayoritas tingkat pendidikan non formal petani responden masuk dalam kategori rendah dan sangat tinggi yakni sebanyak 15 responden
(25,00\%). Rendahnya pendidikan non formal petani pada penelitian ini terjadi karena kurang aktifnya petani dalam mengikuti penyuluhan dan pelatihan, sedangkan kategori sangat tinggi didominasi oleh petani yang aktif dan sudah mengusahakan kelor.

Tingkat pengalaman petani di Desa Kedungbulus Kecamatan Gembong termasuk dalam kategori cukup berpengalaman yakni 24 orang $(40,00 \%)$ karena petanidi Desa Kedungbulus sudah lama menjadi petani dan sebagian besar aktif dalam mengikuti pertemuan kelompok tani. Walgito (1980) juga mengemukakan bahwa sikap seseorang terhadap objek sikap juga dapat dipengaruhi oleh pengalaman langsung dari orang yang bersangkutan dengan objek sikap tersebut.

Pengaruh orang lain yang dianggap penting pada penelitian ini berada pada kategori cukup berpengaruh kepada 18 petani $(30,00 \%)$. Orang lain yang dianggap penting pada penelitian ini adalah penyuluh, Komunitas Pangan Sehat, ketua gapoktan dan petani lain. Apabila ketiga pihak tersebut menyikapi pengembangan potensi kelor dengan baik mereka juga akan bersikap demikian. Hal ini sesuai dengan pendapat Azwar (2013) orang lain di sekitar kita merupakan salah satu diantara komponen sosial yang ikut mempengaruhi sikap kita.

Penelitian ini dilakukan untuk mengetahui hubungan antara faktor-faktor pembentuk sikap dengan sikap masyarakat tani terhadap pengembangan Kampung Kelor. Berdasarkan data analisis Rank Spearman diperoleh hasil sebagai berikut : 
Tabel 3. Hasil Analisis Rank Spearman

\begin{tabular}{llcrr}
\hline \multirow{2}{*}{ No } & Variabel & \multicolumn{3}{c}{ Unstandarized Coefficient } \\
\cline { 2 - 5 } & (Constant) & rs & thit & Keterangan \\
1 & Umur & 0,456 & 3,902 & Signifikan* \\
2 & Pendidikan Formal & 0,344 & 2,790 & Signifikan* \\
3 & Luar Penguasaan Lahan & 0,178 & 1,378 & Tidak Signifikan \\
4 & Pendidikan Non Formal & 0,336 & 2,717 & Signifikan* \\
5 & Pengalaman Usahatani & 0,336 & 2,717 & Signifikan* \\
6 & Pengaruh Orang Laing yang & 0,335 & 2,708 & Signifikan* \\
& Dianggap Penting & & & \\
\hline
\end{tabular}

Keterangan: *) = Berpengaruh nyata pada taraf kepercayaan 95\%

Berdasarkan tabel 3, hubungan antara faktor-faktor pembentuk sikap dengan sikap masyarakat tani terhadap pengembangan Kampung Kelor di Desa Kedungbulus Kecamatan Gembong Kabupaten Pati dapat dijelaskan sebagai berikut:

Hubungan antara umur dengan sikap petani terhadap pengembangan Kampung Kelor.

Nilai koefisien rs sebesar 0,456 pada $\alpha=$ 0,05 dengan $\mathrm{t}_{\text {hitung }}$ sebesar $(3,902)>\mathrm{t}_{\text {tabel }}(2,000)$ maka $\mathrm{H}_{0}$ ditolak dan $\mathrm{H}_{1}$ diterima. Artinya, terdapat hubunganyang signifikan antara umurdengan sikap masyarakat terhadap pengembangan Kampung Kelor di Desa Kedungbulus Kecamatan Gembong Kabupaten Pati pada tingkat kepercayaan 95\%. Hasil penelitian sesuai dengan teori Lewin (1970) dan Green (1991) bahwa semakin bertambahnya umur, minat dan kesetujuan seseorang untuk melakukan suatu kegiatan baru adalah rendah.

\section{Hubungan antara pendidikan formal dengan sikap petani terhadap pengembangan Kampung Kelor.}

Nilai koefisien rs sebesar 0,344 pada $\alpha=$ 0,05 dengan $\mathrm{t}_{\text {hitung }}$ sebesar $(2,790)>\mathrm{t}$ tabel $_{\text {tan }}(2,000)$ maka Ho ditolak. Artinya, terdapat hubungan yang signifikan antara pendidikan formal dengan sikap masyarakat terhadap pengembangan Kampung Kelor di Desa Kedungbulus Kecamatan Gembong Kabupaten Pati pada tingkat kepercayaan 95\%. Hal ini sesuai dengan pernyataan Azwar (2013) bahwa lembaga pendidikan sebagai suatu sistem mempunyai pengaruh dalam pembentukan sikap individu.
Hubungan antara luas penguasaan lahan dengan sikap petani terhadap pengembangan Kampung Kelor

Nilai koefisien rs sebesar 0,178 pada $\alpha=0,05$ dengan $\mathrm{t}_{\text {hitung }}$ sebesar $(1,378)<\mathrm{t}_{\text {tabel }}$ $(2,000)$ maka Ho diterima. Artinya, tidak terdapat hubungan yang signifikan antara luas penguasaan lahan dengan sikap masyarakat terhadap pengembangan Kampung Kelor di Desa Kedungbulus Kecamatan Gembong Kabupaten Pati pada tingkat kepercayaan 95\%. Hubungan yang tidak signifikan menunjukkan bahwa pengembangan Kampung Kelor disikapi baik dan dapat diterima responden baik yang memiliki lahan luas maupun sempit. Hasil tersebut tidak sesuai dengan pernyataan yang dikemukakan oleh Mardikanto (1992) dimana menyatakan bahwa Luas lahan yang dikuasai relatif sempit tidak mudah menerima inovasi atau akan sulit melaksanakan perubahan usahatani atau adopsi teknologi.

Hubungan antara pendidikan non formal dengan sikap petani terhadap pengembangan Kampung Kelor.

Nilai koefisien rs sebesar 0,336 dan nilai $\mathrm{t}_{\text {hitung }}$ sebesar 2,717. Hasil tersebut menunjukkan $\mathrm{t}_{\text {hitung }}(2,717)$ lebih besar daripada $\mathrm{t}_{\text {tabel }}(2,000)$ pada taraf kepercayaan $95 \%$ atau $\alpha=0,05$, maka H0 ditolak, artinya ada hubungan yang signifikan antara pendidikan non formal dengan sikap petani terhadap pengembangan Kampung Kelor di Desa Kedungbulus Kecamatan Gembong Kabupaten Pati. Hasil penelitian sesuai dengan teori 
Mardikanto (1996) yang menyatakan penyuluhan pertanian merupakan suatu sistem pendidikan non formal yang tidak sekedar memberikan penerangan atau menjelaskan, tetapi berupaya untuk mengubah perilaku sasarannya agar memiliki pengetahuan pertanian dan berusaha tani yang luas, memiliki sikap progresif untuk melakukan perubahan dan inovatif terhadap sesuatu (informasi) baru, serta terampil melaksanakan berbagai kegiatan.

Hubungan antara pengalaman usahatani dengan sikap petani terhadap pengembangan Kampung Kelor.

Nilai rs sebesar 0,336 dan nilai t hitung sebesar 2,717. Hasil tersebut menunjukkan t- ${ }_{\text {hitung }}$ $(2,717)$ lebih besar daripada $t_{\text {tabel }}(2,000)$ pada taraf kepercayaan $95 \%$ atau $\alpha=0,05$, maka $\mathrm{H} 0$ ditolak, artinya ada hubungan yang signifikan antara pengalaman usahatani dengan sikap petani terhadap pengembangan Kampung Kelor. Hal ini sesuai dengan pernyataan Rahayuningsih (2008) yaitu semakin lama seseorang memiliki pengalaman pribadi terhadap suatu hal maka akan mempengaruhi sikap seseorang terhadap suatu hal tersebut.

Hubungan antara pengaruh orang lain yang dianggap penting dengan sikap petani terhadap pengembangan Kampung Kelor.

Nilai koefisien rs sebesar 0,335 dan nilai ${ }^{t}{ }_{\text {hitung }}$ sebesar 2,708. Hasil tersebut menunjukkan ${ }^{t}{ }_{\text {hitung }}(2,708)$ lebih besar daripada t- ${ }_{\text {tabel }}(2,000)$ pada taraf kepercayaan $95 \%$ atau $\alpha=0,05$, maka H0 ditolak, artinya ada hubungan yang signifikan antara pengaruh orang lain yang dianggap penting dengan sikap petani terhadap pengembangan Kampung Kelor di Desa Kedungbulus Kecamatan Gembong Kabupaten Pati. Hal ini sesuai dengan pernyataan Azwar (2013) Pada umumnya individu cenderung untuk memiliki sikap yang konformis atau searah dengan sikap orang yang dianggapnya penting.

Perbedaan Sikap antara Masyaraat Tani yang Sudah Mengusahakan Kelor dengan Masyarakat Tani yang Belum Mengusahakan Kelor terhadap Pengembangan Kampung Kelor di Desa Kedungbulus

Penelitian ini menganalisis perbedaan sikap antara masyarakat tani yang sudah mengusahakan kelor dengan yang belum mengusahakan kelor. Analisis perbedaan sikap ini menggunakan uji beda $U$ mann-Whitney yang dihitung dengan program SPSS versi 20 for windows. Uji signifikansi dilakukan dengan cara membandingkan nilai $\mathrm{Z}$ hitung dengan nilai $\mathrm{Z}$ tabel menggunakan tingkat kepercayaan 95\% $(\alpha=0,05)$. Responden dalam penelitian ini berjumlah 60 responden, dengan rincian 34 responden merupakan masyarakat tani yang sudah mengusahakan kelor dan sebanyak 26 masyarakat tani belum mengusahakan kelor. Hasil analisis perbedaan sikap masyarakat terhadap pengembangan Kampung Kelor di Kecamatan Gembong dapat dilihat pada tabel 4.

Tabel 4. Hasil Analisis Uji Beda

\begin{tabular}{lccllll}
\hline $\begin{array}{l}\text { Perbedaan Sikap Masyarakat Tani } \\
\text { terhadap Pengembangan Kampung } \\
\text { kelor }\end{array}$ & N & $\begin{array}{l}\text { Mean } \\
\text { Rank }\end{array}$ & $\begin{array}{l}\text { Sum of } \\
\text { Rank }\end{array}$ & $\begin{array}{l}\text { Mann- } \\
\text { Whitney }\end{array}$ & $\begin{array}{l}\text { Asymp. } \\
\text { Sig } \\
\text { (2-tailed) }\end{array}$ & Zhit \\
\hline $\begin{array}{l}\text { Petani yang sudah mengusahakan kelor } \\
\begin{array}{l}\text { Petani yang belum mengusahakan kelor } \\
24\end{array}\end{array}$ & $\begin{array}{l}35,72 \\
23,67\end{array}$ & $\begin{array}{l}1214,50 \\
615,50\end{array}$ & 264,500 & 0,008 & 2,653 \\
\hline
\end{tabular}

Berdasarkan tabel 4, Hasil perhitungan uji beda menunjukkan nilai Mann-Whitney sebesar 264,50 dan nilai Asymp. Sig. sebesar 0,008 dan nilai $Z_{\text {hitung }}$ sebesar 2,653. Maka $Z_{\text {hitung }}>Z_{\text {tabel }}$ yaitu $2,653>1,96$ sehingga $\mathrm{H}_{0}$ ditolak. Artinya terdapat perbedaan sikap yang signifikan antara masyarakat tani yang sudah mengusahakan kelor dan masyarakat tani yang belum mengusahakan kelor terhadap pengembangan Kampung Kelor di Desa Kedungbulus. Mengenai tujuan pengembangan Kampung Kelor, masyarakat tani yang sudah mengusahakan kelor memiliki informasi yang lebih jelas dan detail. Masyarakat yang sudah mengusahakan dapat dikatakan lebih paham mengenai pengembangan Kampung Kelor dan secara langsung sudah dapat merasakan 
Tabel 3. Hasil Analisis Rank Spearman

\begin{tabular}{llccr}
\hline \multirow{2}{*}{ No } & Variabel & \multicolumn{3}{c}{ Unstandarized Coefficient } \\
\cline { 2 - 5 } & (Constant) & rs & thit & Keterangan \\
1 & Umur & 0,456 & 3,902 & Signifikan* \\
2 & Pendidikan Formal & 0,344 & 2,790 & Signifikan* \\
3 & Luar Penguasaan Lahan & 0,178 & 1,378 & Tidak Signifikan \\
4 & Pendidikan Non Formal & 0,336 & 2,717 & Signifikan* \\
5 & Pengalaman Usahatani & 0,336 & 2,717 & Signifikan* \\
6 & Pengaruh Orang Laing yang & 0,335 & 2,708 & Signifikan* \\
& Dianggap Penting & & & \\
\hline
\end{tabular}

Keterangan: $*$ ) = Berpengaruh nyata pada taraf kepercayaan 95\%

Berdasarkan tabel 3, hubungan antara faktor-faktor pembentuk sikap dengan sikap masyarakat tani terhadap pengembangan Kampung Kelor di Desa Kedungbulus Kecamatan Gembong Kabupaten Pati dapat dijelaskan sebagai berikut:

Hubungan antara umur dengan sikap petani terhadap pengembangan Kampung Kelor.

Nilai koefisien rs sebesar 0,456 pada $\alpha=$ 0,05 dengan $\mathrm{t}_{\text {hitung }}$ sebesar $(3,902)>\mathrm{t}_{\text {tabel }}(2,000)$ maka $\mathrm{H}_{0}$ ditolak dan $\mathrm{H}_{1}$ diterima. Artinya, terdapat hubunganyang signifikan antaraumur dengan sikap masyarakat terhadap pengembangan Kampung Kelor di Desa Kedungbulus Kecamatan Gembong Kabupaten Pati pada tingkat kepercayaan 95\%. Hasil penelitian sesuai dengan teori Lewin (1970) dan Green (1991) bahwa semakin bertambahnya umur, minat dan kesetujuan seseorang untuk melakukan suatu kegiatan baru adalah rendah.

\section{Hubungan antara pendidikan formal dengan sikap petani terhadap pengembangan Kampung Kelor.}

Nilai koefisien rs sebesar 0,344 pada $\alpha=$ 0,05 dengan $\mathrm{t}_{\text {hitung }}$ sebesar $(2,790)>\mathrm{t}$ tabel $_{\text {tabl }}(2,000)$ maka Ho ditolak. Artinya, terdapat hubungan yang signifikan antara pendidikan formal dengan sikap masyarakat terhadap pengembangan Kampung Kelor di Desa Kedungbulus Kecamatan Gembong Kabupaten Pati pada tingkat kepercayaan 95\%. Hal ini sesuai dengan pernyataan Azwar (2013) bahwa lembaga pendidikan sebagai suatu sistem mempunyai pengaruh dalam pembentukan sikap individu.

Hubungan antara luas penguasaan lahan dengan sikap petani terhadap pengembangan Kampung Kelor

Nilai koefisien rs sebesar 0,178 pada $\alpha=0,05$ dengan $\mathrm{t}_{\text {hitung }}$ sebesar $(1,378)<\mathrm{t}_{\text {tabel }}$ $(2,000)$ maka Ho diterima. Artinya, tidak terdapat hubungan yang signifikan antara luas penguasaan lahan dengan sikap masyarakat terhadap pengembangan Kampung Kelor di Desa Kedungbulus Kecamatan Gembong Kabupaten Pati pada tingkat kepercayaan 95\%. Hubungan yang tidak signifikan menunjukkan bahwa pengembangan Kampung Kelor disikapi baik dan dapat diterima responden baik yang memiliki lahan luas maupun sempit. Hasil tersebut tidak sesuai dengan pernyataan yang dikemukakan oleh Mardikanto (1992) dimana menyatakan bahwa Luas lahan yang dikuasai relatif sempit tidak mudah menerima inovasi atau akan sulit melaksanakan perubahan usahatani atau adopsi teknologi.

Hubungan antara pendidikan non formal dengan sikap petani terhadap pengembangan Kampung Kelor.

Nilai koefisien rs sebesar 0,336 dan nilai t- hitung sebesar 2,717. Hasil tersebut menunjukkan t- ${ }_{\text {hitung }}(2,717)$ lebih besar daripada $\mathrm{t}_{\text {tabel }}(2,000)$ pada taraf kepercayaan $95 \%$ atau $\alpha$ $=0,05$, maka H0 ditolak, artinya ada hubungan yang signifikan antara pendidikan non formal 
dengan sikap petani terhadap pengembangan Kampung Kelor di Desa Kedungbulus Kecamatan Gembong Kabupaten Pati. Hasil penelitian sesuai dengan teori Mardikanto (1996) yang menyatakan penyuluhan pertanian merupakan suatu sistem pendidikan non formal yang tidak sekedar memberikan penerangan atau menjelaskan, tetapi berupaya untuk mengubah perilaku sasarannya agar memiliki pengetahuan pertanian dan berusaha tani yang luas, memiliki sikap progresif untuk melakukan perubahan dan inovatif terhadap sesuatu (informasi) baru, serta terampil melaksanakan berbagai kegiatan.

Hubungan antara pengalaman usahatani dengan sikap petani terhadap pengembangan Kampung Kelor.

Nilai rs sebesar 0,336 dan nilai t- ${ }_{\text {hitung }}$ sebesar 2,717. Hasil tersebut menunjukkan $\mathrm{t}_{-}{ }_{\text {hitung }}$ $(2,717)$ lebih besar daripada t- ${ }_{\text {tabel }}(2,000)$ pada taraf kepercayaan $95 \%$ atau $\alpha=0,05$, maka $\mathrm{H} 0$ ditolak, artinya ada hubungan yang signifikan antara pengalaman usahatani dengan sikap petani terhadap pengembangan Kampung Kelor. Hal ini sesuai dengan pernyataan Rahayuningsih (2008) yaitu semakin lama seseorang memiliki pengalaman pribadi terhadap suatu hal maka akan mempengaruhi sikap seseorang terhadap suatu hal tersebut.
Hubungan antara pengaruh orang lain yang dianggap penting dengan sikap petani terhadap pengembangan Kampung Kelor.

Nilai koefisien rs sebesar 0,335 dan nilai ${ }^{t}{ }_{\text {hitung }}$ sebesar 2,708. Hasil tersebut menunjukkan ${ }^{t}{ }_{\text {hitung }}(2,708)$ lebih besar daripada t-tabel $(2,000)$ pada taraf kepercayaan $95 \%$ atau $\alpha=0,05$, maka H0 ditolak, artinya ada hubungan yang signifikan antara pengaruh orang lain yang dianggap penting dengan sikap petani terhadap pengembangan Kampung Kelor di Desa Kedungbulus Kecamatan Gembong Kabupaten Pati. Hal ini sesuai dengan pernyataan Azwar (2013) Pada umumnya individu cenderung untuk memiliki sikap yang konformis atau searah dengan sikap orang yang dianggapnya penting.

Perbedaan Sikap antara Masyaraat Tani yang Sudah Mengusahakan Kelor dengan Masyarakat Tani yang Belum Mengusahakan Kelor terhadap Pengembangan Kampung Kelor di Desa Kedung bulus

Penelitian ini menganalisis perbedaan sikap antara masyarakat tani yang sudah mengusahakan kelor dengan yang belum mengusahakan kelor. Analisis perbedaan sikap ini menggunakan uji beda $U$ mann-Whitney yang dihitung dengan program SPSS versi 20 for windows. Uji signifikansi dilakukan dengan cara membandingkan nilai $\mathrm{Z}$ hitung dengan nilai $\mathrm{Z}$ tabel menggunakan tingkat kepercayaan 95\% $(\alpha=0,05)$. Responden dalam penelitian ini berjumlah 60 responden, dengan rincian 34 responden merupakan masyarakat tani yang sudah mengusahakan kelor dan sebanyak 26 masyarakat tani belum mengusahakan kelor. Hasil analisis perbedaan sikap masyarakat terhadap pengembangan Kampung Kelor di Kecamatan Gembong dapat dilihat pada tabel 4 .

Tabel 4. Hasil Analisis Uji Beda

\begin{tabular}{lcccccc}
\hline $\begin{array}{l}\text { Perbedaan Sikap Masyarakat Tani } \\
\text { terhadap Pengembangan Kampung kelor }\end{array}$ & N & $\begin{array}{l}\text { Mean } \\
\text { Rank }\end{array}$ & $\begin{array}{l}\text { Sum of } \\
\text { Rank }\end{array}$ & $\begin{array}{l}\text { Mann- } \\
\text { Whitney }\end{array}$ & $\begin{array}{l}\text { Asymp. } \\
\text { Sig } \\
\text { (2-tailed) }\end{array}$ & Zhit \\
\hline Petani yang sudah mengusahakan kelor & 34 & 35,72 & 1214,50 & & & \\
Petani yang belum mengusahakan kelor & 26 & 23,67 & 615,50 & 264,500 & 0,008 & 2,653 \\
\hline
\end{tabular}


Berdasarkan tabel 4, Hasil perhitungan uji beda menunjukkan nilai Mann-Whitney sebesar 264,50 dan nilai Asymp. Sig. sebesar 0,008 dan nilai $\mathrm{Z}_{\text {hitung }}$ sebesar 2,653. Maka $\mathrm{Z}_{\text {hitung }}>\mathrm{Z}_{\text {tabel }}$ yaitu 2,653 $>1,96$ sehingga $\mathrm{H}_{0}$ ditolak. Artinya terdapat perbedaan sikap yang signifikan antara masyarakat tani yang sudah mengusahakan kelor dan masyarakat tani yang belum mengusahakan kelor terhadap pengembangan Kampung Kelor di Desa Kedungbulus. Mengenai tujuan pengembangan Kampung Kelor, masyarakat tani yang sudah mengusahakan kelor memiliki informasi yang lebih jelas dan detail. Masyarakat yang sudah mengusahakan dapat dikatakan lebih paham mengenai pengembangan Kampung Kelor dan secara langsung sudah dapat merasakan manfaat dari tujuan pengembangan. Beberapa masyarakat tani yang belum mengusahakan jarang mengikuti perkumpulan sehingga tidak banyak mendapatkan informasi yang jelas terkait pengembangan Kampung Kelor. Hal ini sesuai dengan pernyataan Maryati (2001) menyatakan bahwa adanya perbedaan status (kedudukan) seseorang dapat mempengaruhi seseorang dalam bersikap dan berperilaku.

\section{KESIMPULAN DAN SARAN}

\section{Kesimpulan}

Berdasarkan hasil analisis dan pembahasan yang telah dilakukan, maka diperoleh kesimpulan sebagai berikut: Sikap masyarakat tani terhadap Pengembangan Kampung Kelor di Desa Kedungbulus Kecamatan Gembong Kabupaten Pati adalah baik. Faktor umur, faktor pendidikan formal, faktor pendidikan non formal, faktor pengalaman usahatani, dan faktor pengaruh oranglain yang dianggap penting berhubungan signifikan terhadap sikap masyarakat tani terhadap pengembangan Kampung Kelor sedangkan faktor luas penguasaan lahan tidak berhubungan signifikan terhadap sikap masyarakat tani terhadap pengembangan Kampung Kelor. Terdapat perbedaan sikap yang signifikan antara masyarakat tani yang sudah mengusahakan kelor dengan masyarakat tani yang belum mengusahakan kelor terhadap pengembangan Kampung Kelor. Masyarakat tani yang sudah mengusahakan kelor memiliki sikap yang lebih baik daripada masyarakat yang belum mengusahakan kelor.

\section{Saran}

Berdasarkan hasil penelitian dan kesimpulan pada penelitian ini dapat diajukan saran sebagai berikut: Masyarakat tani diharapkan dapat terus mendukung pengembangan Kampung Kelor di Desa Kedungbulus dan terlibat aktif dalam gerakan penanaman serta pengusahaan kelor. Masyarakat tani diharapkan dapat aktif mengikuti pertemuan kelompok tani, sosialisasi, pelatihan maupun penyuluhan agar dapat menambah informasi mengenai kegiatan usahatani khususnya kelor dan dapat memecahkan masalah mereka terkait bidang pertanian. Penyuluh, Komunitas Pangan Sehat (KPS) Kabupaten Pati, dan ketua kelompok tani serta petani lain diharapkan dapat mempertahankan serta meningkatkan antusias masyarakat terkait budidaya dan pengolahan kelor dengan cara mengadakan kegiatan pelatihan maupun pertemuan secara rutin terkait pengembangan Kampung Kelor. Masyarakat tani yang belum mengusahakan kelor diharapkan mau dan dapat terlibat langsung serta aktif mendukung pengembangan kampung kelor sehingga dapat tercipta kesetaraan sikap yakni sikap yang baik sehingga tujuan pengembangan Kampung Kelor dapat tercapai.

\section{DAFTAR PUSTAKA}

Adedokum, M.O., Oladoye, A.O., Olawumi, A.T. and Laminou, K.I. 2010. Economic contribution of Moringa oleifera (Lam) plantation of rural livelihoods in Monoidi Local Government Area of Niger Republic. Obeche Journal 28(2):142-146.

Azwar, S. 2013. Sikap Manusia. Pustaka Pelajar: Yogyakarta.

Badan Pusat Statistik Pusat. 2017. Angka Kemiskinan Penduduk Indonesia dan Rumah Tangga. https://bps.go.id/__Diakses pada 10 Agustus 2018.

Darwis, K. 2017. Ilmu Usahatani. Inti Mediatama: Makasar.

Green, L.W. dan Kreuter, M.W. 1991. Health Promotion Planning An Educational and Environmental Approach. Mayfield Publising Company: Landon. 
Irfai, M. 2011. Kelor. Widyaiswara Muda Balai Diklat: Surabaya.

Lewin, Kurt. 1951. Field Theory in Social Science, Selected Theoretical Papers. Harper \& Brothers: New York.

Manatar, P.M., Laoh, H.E., Mandei, R.J. 2017. Pengaruh Status Penguasaan Lahan terhadap Pendapatan Petani Padi di Desa Tumani, Kecamatan Maesaan, Kabupaten Minahasa Selatan. Agri-SosioEkonomi Unsrat 13(1): 55-64.

Mardikanto, T. 1992. Penyuluhan Pembangunan Pertanian. Surakarta: Sebelas Maret University Press

Mardikanto, $\mathrm{T}$ dan Sri Sutarni. 1996. Penyuluhan Pembangunan Kehutanan. Departemen Kehutanan: Jakarta.

Maryati,kun dan Juju Suryawati.2001.Sosiologi untuk SMA dan MA. Erlangga: Jakarta

Omotesho, K.F., Solaojo, F.E., Fayeye, T.R., Babatunde, R.O., Otunola, G.A., Aliyu, T.H. 2013. The potential of Moringa tree for poverty alleviation and rural development: review of evidences on usage and efficacy. $J$. International of Development and Sustainability 2(2):799-813

Oskamp, S. and Wesley, S. 2014. Attitudes and Opinions.Psychology Press: New York

Radovich, T. 2010. Farm and forestry production and marketing profile for Moringa (Moringa oleifera) In: Elevitch, C.R. (ed.). Specialty crops for Pacific Island Agro forestry. Permanent Agricultural Recourses Holualoa: Hawaii.

Rahayuningsih, S.U. 2008. Psikologi Umum (2). Uiversitas Gadjah Mada: Yogyakarta

Rusmani. 2018. Wawancara "Kampung Kelor" di Desa Kedungbulus Kecamatan Gembong Kabupaten Pati.
Singarimbun, M dan S. Effendi. 1989. Metode Penelitian Survey. LP3ES: Jakarta. Undang-Undang Republik Indonesia Nomor 18 Tahun 2012 Tentang Pangan Undang-undang Republik Indonesia Nomor 6 Tahun 2014 tentang Desa Walgito, B. 1980. Psikologi Sosial. CV Andi Offset: Yogyakarta. 